\title{
EFFECT OF ETHANOL EXTRACT OF DATE PALM FRUIT (Phoenix dactylifera. L) ON SPERMATOZOA CONCENTRATION OF Balb/c MICE (Mus musculus) EXPOSED TO 2- METHOXYETHANOL
}

\author{
Tita Rudini Yassin', Rina Yaudiwati' ${ }^{2}$, Reny I'tishom² \\ ${ }^{1}$ Master Program of Reproductive Health, ${ }^{2}$ Department of Medical Biology, Faculty of Medicine, Universitas \\ Airlangga, Surabaya, Indonesia
}

\section{ABSTRACT}

\begin{abstract}
Antioxidants are important compounds for the human body because they function to capture free radicals causing degenerative diseases. Flavonoid and phenolic compounds in dates have antioxidant activity that can inhibit the increase in lipid peroxide and protein oxide. This study aims to prove the increase in the concentration of mice (Mus musculus) spermatozoa given ethanol extract dates and exposed to 2-methoxyethanol. Experimental animals used 35 mice (Mus musculus), divided into 5 groups ( 7 mice per group). The negative control group $(K-)$ was the control group without administration of 2-methoxyethanol and date ethanol extract, the positive control group $(\mathrm{K}+)$ was given $200 \mathrm{mg} / \mathrm{kg} 2$-methoxyethanol $+C M C 0.5 \%$, the treatment group 1 (P1) was given $200 \mathrm{mg} / \mathrm{kg} \mathrm{BW} \mathrm{2-methoxyethanol}+3.5 \mathrm{mg} / \mathrm{gBW}$ of ethanol extract dates, treatment group $2(P 2)$ were given $200 \mathrm{mg} / \mathrm{kg} \mathrm{BW} 2$-methoxyethanol $+7 \mathrm{mg} / \mathrm{gBW}$ of date palm ethanol extract, and treatment group 3 (P3) were given 200 $\mathrm{mg} / \mathrm{kg}$ 2-methoxyethanol $+10.5 \mathrm{mg} / \mathrm{gBW}$ of ethanol extract dates. The results showed there were significant differences in spermatozoa concentrations between the positive control group $(K+)$ and the negative control group $(K$-), treatment group 1 (P1) and treatment groups 2 and 3. mice (Mus musculus) exposed to 2-methoxyethanol.
\end{abstract}

Keywords: Ethanol extract of dates; 2-methoxyethanol; spermatozoa concentration

\section{ABSTRAK}

\begin{abstract}
Antioksidan merupakan senyawa penting bagi tubuh manusia karena berfungsi untuk menangkap radikal bebas yang dapat menyebabkan terjadinya penyakit degeneratif. Senyawa flavonoid dan fenolik dalam buah kurma memiliki aktivitas antioksidan yang dapat menghambat kenaikan lipid peroksida dan protein oksida. Penelitian ini bertujuan untuk membuktikan peningkatan konsentrasi spermatozoa mencit (Mus musculus) yang diberi ekstrak etanol kurma dan dipapar 2-methoxyethanol. Hewan coba menggunakan mencit (Mus musculus) sejumlah 35 ekor, dibagi menjadi 5 kelompok (7 ekor mencit per kelompok). Kelompok kontrol negatif $(K-)$ adalah kelompok kontrol tanpa pemberian 2-methoxyethanol dan ekstrak etanol kurma, Kelompok kontrol positif $(\mathrm{K}+)$ diberi $200 \mathrm{mg} / \mathrm{kgBB}$ 2-methoxyethanol + CMC 0,5\%, kelompok perlakuan 1 (P1) diberi $200 \mathrm{mg} / \mathrm{kgBB} 2-$ methoxyethanol $+3,5 \mathrm{mg} / \mathrm{gBB}$ ekstrak etanol kurma, kelompok perlakuan $2(P 2)$ diberi $200 \mathrm{mg} / \mathrm{kg}$ BB 2-methoxyethanol +7 $\mathrm{mg} / \mathrm{gBB}$ ekstrak etanol kurma, dan kelompok perlakuan 3 (P3) diberi $200 \mathrm{mg} / \mathrm{kg} \mathrm{BB} \mathrm{2-methoxyethanol}+10,5 \mathrm{mg} / \mathrm{gBB}$ ekstrak etanol kurma. Hasil penelitian menunjukkan ada perbedaan signifikan pada konsentrasi spermatozoa antara kelompok kontrol positif $(K+)$ dengan kelompok kontrol negatif $(K-)$, kelompok perlakuan $1(P 1)$ dan kelompok perlakuan 2 dan 3, Kesimpulan penelitian ini adalah ekstrak etanol kurma terbukti dapat meningkatkan konsentrasi spermatozoa mencit (Mus musculus) yang dipapar 2-methoxyethanol.
\end{abstract}

Kata kunci: Ekstrak etanol kurma; 2-methoxyethanol; konsentrasi spermatozoa

Correspondence: Tita Rudini Yassin, Master Program of Reproductive Health, Faculty of Medicine, Universitas Airlangga, Jl. Prof. Dr. Moestopo 47, Surabaya 60131 Indonesia. Phone: 031-5501617.

E-mail: titazakki@gmail.com

pISSN:2355-8393 • eISSN: 2599-056x • doi: http://dx.doi.org/10.20473/fmi.v56i2.21189

- Fol Med Indones. 2020;56:82-85 • Received 31 Jan 2017 • Accepted 20 Jul 2017

- Open access under CC-BY-NC-SA license • Available at https://e-journal.unair.ac.id/FMI/

\section{INTRODUCTION}

2-methoxyethvanol is a chemical that is very dangerous to human safety including reproductive function. This compound is widely used as a solvent for organic water- based materials in industries and household appliances (Starek et al 2010). Long-term exposure to 2methoxyethanol can disrupt the male reproductive system by affecting the production or maturation process of spermatozoa (concentration, motility, and 
morphology) (Giwercman \& Bonde 1998). In vitro research shows that 2-methoxyethanol can inhibit the production of lactic acid in Sertoli cell culture so that it can interfere with the growth of spermatocytes, because lactate is an important component as an energy source for growing spermatocytes. 2-methoxyethanol in the body is oxidized by alcohol dehydrogenase to methoxyacetaldehyde (MALD) which is then metabolized into Methoxyacetic acid (MAA) which is toxic by dehydrogenase. Methoxyacetic acid as a result of the metabolism of 2-methoxyethanol is a strong oxidant that can cause oxidative stress in spermatozoa. Oxidation stress is caused by the formation of reactive oxygen species (ROS). Very high levels of ROS not only affect the integrity of DNA in the nucleus of spermatozoa, but also the flexibility of cell membranes thereby reducing the quality of spermatozoa (Hayati et al 2004). Dates contain high antioxidants in the form of flavonoids. Flavonoid glucoside is the highest number of flavonoid compounds in the extract of dates (Al Haija, 2011). This type of flavonoid is known to inhibit and eliminate free radicals due to exposure to chemicals one of which is 2methoxyethanol. It is expected that this date extract can improve the concentration of spermatozoa which may later have an impact on infertility.

\section{MATERIALS AND METHODS}

This was an experimental study with a research design using the post test only control group design approach. The research used experimental animals of Balb/c male mice which were given ethanol extract dates orally and 2-methoxyethanol sub cutaneous. Experimental animals were divided into five groups, namely one negative control group, one positive control group, and three treatment groups. All mice (Mus musculus) test animals were first grouped into 5 groups with 7 animals in each group. Furthermore, the test animals were given the following treatment. The first group was given aquadest $0.1 \mathrm{ml} /$ day. The second group was given 2methoxyethanol dose $200 \mathrm{mg} / \mathrm{kgBW}$ for 5 days, followed by $0.5 \% \mathrm{CMC}$ for 47 days. the third group was given 2-methoxyethanol at a dose of $200 \mathrm{mg} / \mathrm{kg} \mathrm{BW}$ for 5 days, followed by ethanol extract dates $3.5 \mathrm{mg} / \mathrm{g} \mathrm{BW}$ for 47 days. the fourth group was given 2methoxyethanol dose $200 \mathrm{mg} / \mathrm{kg} \mathrm{BW}$ for 5 days, followed by ethanol extract dates $7 \mathrm{mg} / \mathrm{g}$ BW for 47 days and the fifth group was given 2-methoxyethanol dose $200 \mathrm{mg} / \mathrm{kg} \mathrm{BW}$ for 5 days, followed by ethanol extract dates $10,5 \mathrm{mg} / \mathrm{g} \mathrm{BW}$ for 47 days.On day 52 , mice were sacrificed and semen analysis was examined to determine the concentration of spermatozoa in the control group and the treatment group.

\section{RESULTS}

The results of this study indicated that the mean concentration of spermatozoa in the positive control group $(\mathrm{K}+)$ had decreased compared to the negative control (K-). The mean concentration in all treatment groups (P1, P2, P3) increased when compared to the positive control group $(\mathrm{K}+)$, while the positive control group $(\mathrm{K}+)$ decreased when compared to the negative control group (K-). The average concentration of spermatozoa can be seen in Table 1.

Test the normality of spermatozoa concentration by using the One Sample Kolmogorov Smirnov test with $\alpha=0.05$ obtained $p$-value $=0.665$. This can be interpreted that the spermatozoa concentration data were normally distributed. Homogeneity variance test using Levene's Test with $\alpha=0.05$ obtained $p$-value $=0.127$. This can be interpreted that the spermatozoa concentration data were homogeneous.

Spermatozoa concentration data were normally distributed and homogeneous, so the analysis test used is One-way Anova as a variance analysis test. One-way Anova test results showed $\alpha=0.05$ and $p$-value $=0.012$. This can be interpreted that there are significant differences between groups $\mathrm{K}-, \mathrm{K}+, \mathrm{P} 1, \mathrm{P} 2$ and P3.

Table 1. Average concentrations of spermatozoa in $\mathrm{K}-, \mathrm{K}+, \mathrm{P} 1, \mathrm{P} 2$, and $\mathrm{P} 3$

\begin{tabular}{lcccc}
\hline \multicolumn{1}{c}{ Groups } & Mean & SD & Minimum & Maximum \\
\hline $\mathrm{K}(-)$ & $8.78^{\mathrm{a}}$ & 2.72 & 4.58 & 11.90 \\
$\mathrm{~K}(+)$ & $4.71^{\mathrm{b}}$ & 1.41 & 2.70 & 7.08 \\
$\mathrm{P} 1$ & $7.28^{\mathrm{a}}$ & 1.22 & 5.80 & 9.48 \\
$\mathrm{P} 2$ & $7.60^{\mathrm{a}}$ & 1.68 & 5.18 & 10.20 \\
P3 & $7.95^{\mathrm{a}}$ & 2.77 & 4.05 & 11.75 \\
\hline
\end{tabular}

Different superscript letters indicate significant differences with the double comparison test $(\mathrm{p}<0.05)$ 


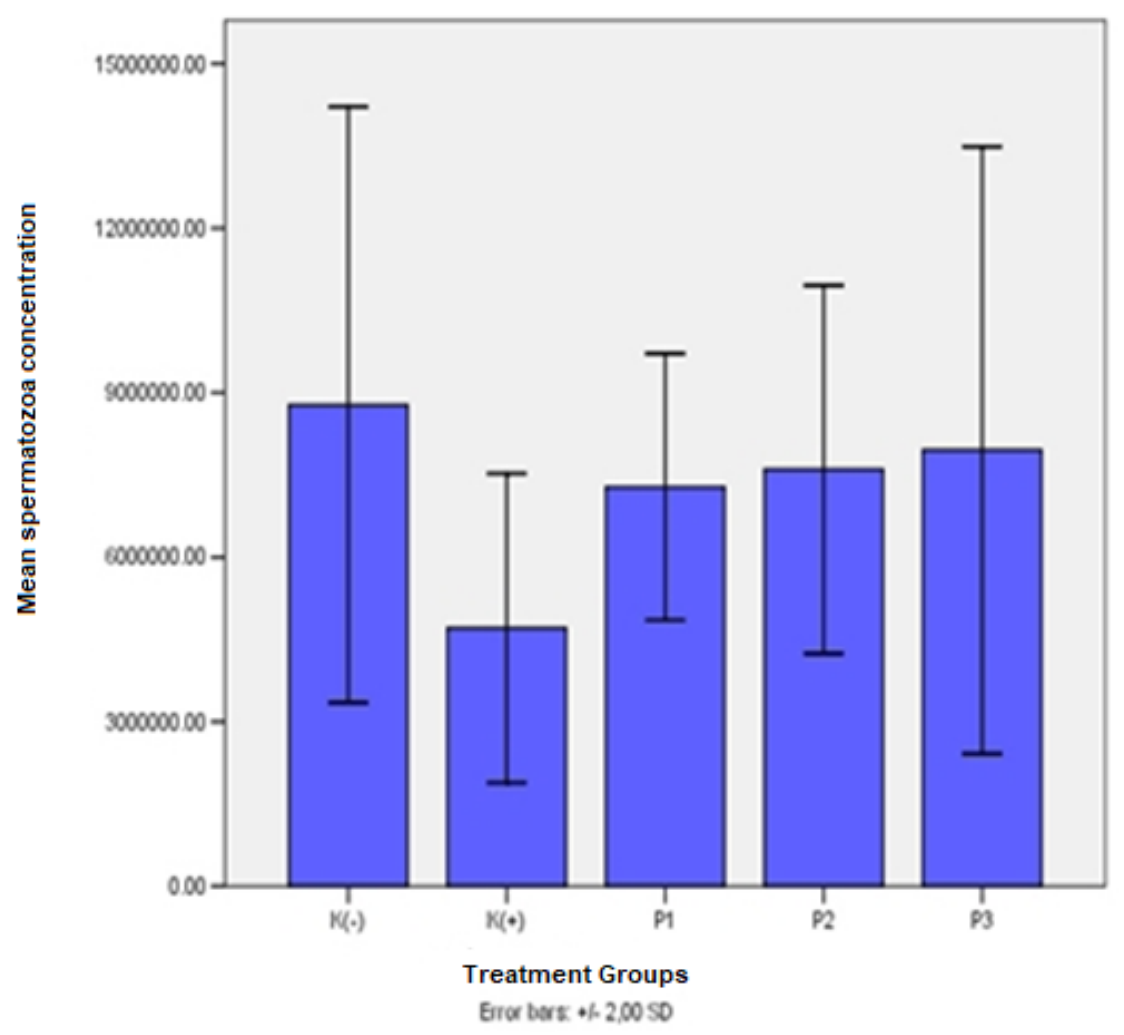

Fig. 1. Mean spermatozoa concentration in the treatment groups.

The results of the mean concentrations in Fig. 1 showed that the group with 2-methoxyethanol dose $200 \mathrm{mg} / \mathrm{kg}$ exposure on days $1-5$ + ethanol extract dates $3.5 \mathrm{mg} / \mathrm{kg}$ BW on days 6-52 (P1), 2-methoxyethanol exposure dose of $200 \mathrm{mg} / \mathrm{kg}$ on days $1-5+$ ethanol extract of dates $7 \mathrm{mg} / \mathrm{kg} \mathrm{BW}$ on days 6-52 (P2), and exposure to 2-methoxyethanol dose of $200 \mathrm{mg} / \mathrm{kg}$ on days $1-5+$ of date palm ethanol extract $10.5 \mathrm{mg} / \mathrm{kg}$ body weight on days 6-52 (P3) showed a higher mean spermatozoa concentration compared to the group with 2methoxyethanol dose $200 \mathrm{mg} / \mathrm{kg}+0.5 \%$ CMC exposure on days 6-52 $(\mathrm{K}+)$, but lower than the group with 0.1 $\mathrm{ml} /$ day (K-) aquadest exposure. This can be interpreted that giving exposure to 2-methoxyethanol at a dose of $200 \mathrm{mg} / \mathrm{kg}$ can reduce the concentration of spermatozoa, while the administration of date palm ethanol extract can increase the concentration of spermatozoa.

\section{DISCUSSION}

The results showed that there was an increase in the concentration of spermatozoa in all treatment groups given dates ethanol extract compared with the positive control group that had been given exposure to 2methoxyethanol. Giving 2-methoxyethanol can reduce the concentration, motility, and morphology of spermatozoa because 2-methoxyethanol which is metabolized by the body will form a free radical and produce ROS. Excessive amounts of free radicals will trigger oxidative stress in the brain and testicles. Oxidative stress that occurs in the brain will interfere with the work of the anterior pituitary in secreting reproductive hormones namely $\mathrm{LH}$ and FSH so that it can affect the target organ of the testes in the process of spermatogenesis so as to cause a decrease in spermatozoa concentration.

In this study, mice (Mus musculus) as experimental animals were given a dose of 2-methoxyethanol as much as $200 \mathrm{mg} / \mathrm{kgBW}$ on days $1-5$. These results are in line with research by Hayati et al (2004) which states that the 2-methoxyethanol compound given to male mice with a dose of $200 \mathrm{mg} / \mathrm{kgBW}$ on days $1-5$ is known to cause a decrease in the number of spermatogonia, primary spermatocytes, and round spermatocytes. Increased membrane permeability can cause decreased spermatozoa motility and dysfunction of Leydig cells and Sertoli cells. In addition, this can also result in enzyme inactivation, damage to DNA structure by stimulating the formation of DNA-based additives resulting in DNA fragmentation and resulting in cell death that can ultimately lead to a decrease in spermatozoa quality (Hamada et al 2011). 
The content of various nutrients in dates provide many benefits for the body. The main components of the dates are protein $(2.3-5.6 \%)$, fat $(0.2-0.5 \%)$, minerals (1$1.9 \%)$, fiber $(6.4-11.5 \%)$, vitamins $(\mathrm{C}, \mathrm{B} 1, \mathrm{~B} 2, \mathrm{~B} 3$ and A), organic acids and polyphenols. In addition to nutritional value and biochemical aspects, dates have biological and pharmacological properties, such as antimutagenic, antioxidant, anticancer, anti-inflammatory, antimicrobial and gastroprotective properties (Baliga et al 2010). Dates contain high antioxidants in the form of flavonoids. Flavonoid glucoside is the highest number of flavonoid compounds in the extract of dates. This type of Flavonoid is known to inhibit and eliminate free radicals due to chemical exposure. Glavonoid glucoside has potential as an antioxidant. Glavonoid glucoside, which is found in dates, is a type of compound that is not conjugated with glucose.

\section{CONCLUSION}

The administration of date palm ethanol extract has been proven to increase spermatozoa concentration even though the spermatozoa concentration is still lower than the spermatozoa concentration without exposure to 2- methoxyethanol. This active substance contained in date palm ethanol extract has a role in increasing the average spermatozoa concentration in all treatment groups.

\section{REFERENCES}

Baliga MS, et al (2010). A review of the chemistry and pharmacology of the date fruits (Phoenix dactylifera $L)$. Food Research International, In Press, Accepted Manuscript.

Giwercman A, Bonde JP (1998). Declining male fertility and environmental factors. Endocrinol Metab Clin North Am 27, 807-830

Hamada A, Esteves SC, Agarwal A (2012). Unexplained infertility-looking beyond routine semen analysis. Eur Urol Rev 7, 90-6

Hayati A, Yunaida B, Pidada IBR, Darmanto W, Winarni D (2004). Efek 2-methoxyethanol terhadap Struktur Histologi Mencit (Mus musculus). Penelitian Berkala Hayati 10, 7-12

Starek AK, Miranowicz-Dzierzawska B, StarekSwiechowicz (2010). Interactive affect of combined exposure to ethylene glycol ethers and ethanolon hematological parametersin rats. Health 2, 1054-1064 